\title{
TAX ANALYSIS OF MARRIED WOMEN HAVING AN INCOME FROM ONE EMPLOYER
}

\author{
Wijaya Suparna \\ Polytechnic of State Finance STAN, Indonesia \\ E-mail: sprnwijaya@pknstan.ac.id
}

\begin{abstract}
Tax regulation applied in Indonesia for married women having an income from one employer and choosing to exercise tax rights and obligations jointly with her husband, is different with to those choosing to exercise rights and obligations separately from her husband, in term of the calculation of income tax payable. This paper aims to understand the regulations of taxation for married women having an income from one employer, both of which exercise tax rights and obligations jointly with her husband or separately from her husband, related to tax provisions, the calculation of income tax, and the impact of the implementation of different regulations for both. This study uses descriptive qualitative research. The method used in this research is qualitative method with descriptive approach. The result of the study indicates that there are significant differences in tax payments between the two married women. Furthermore, married women having an income from one employer knows the consequences of each regulation applied to her so that they have the discretion to determine the choice whether to exercise them jointly with her husband or separately from her husband, without any coercion of situations and conditions.
\end{abstract}

\section{KEY WORDS}

Tax, married women, income, regulations.

Nowadays, the increase of the number of working women in Indonesia is due to the current development in this era of globalization that provides many opportunities for married women who want to work to earn money for the family. The supply and demand of female workers increase with the improvement of the level of women's education that cannot be separated from the role of those who fight for the fate of Indonesian women to get the widest opportunity in achieving high education. Another factor affecting the increase of today's number of working women is economic growth leading to higher cost of living when it is only supported by a single worker in the family; thus, it encourages married women to enter jobs, (Blundell et al, 2000). Nowadays, the high number of married women who enter the world of work is not separated from their status as tax subject who requires them to meet the taxation aspect (Eissa and Hoynes, 2004).

Article 2 of the Constitution No. 6 of 1983, which had changed several times currently with the Constitution No. 16 of 2009 on General Terms and Procedures of Taxation, mention that every tax subject who has met the subjective or objectives requirements, are required to register themselves to Directorate General Tax office and are given Tax Identification Number (TIN). Those who have been registered as subject tax as mandated in Constitution, do not distinguish sex in the fulfillment of taxation rights and obligations so that the position between man and women are equivalent. However, the problems arise in counting tax for married women choosing to exercise tax rights and obligations jointly with her husband and married woman choosing to exercise rights and obligations separately from her husband, (Eissa and Hoynes, 2006).

Regulations of Indonesian taxation apply family as an economic entity, it means that the income or the loss of all family members is combined as a taxable entity and the fulfillment of tax obligations is done by the head of the family. For married women who choose to exercise their rights and obligations of taxation separately from their husbands, the married woman must perform self-assessment system in which they have to register, count, calculate, pay, and report the amount of tax owed irrespective of taxation rights and obligations of her husband, including the ownership of TIN (NPWP) and reporting of Annual 
Tax Return (SPT). The implementation of a separate self-assessment is limited to the exercise of rights and obligations in the field of taxation (Meyer and Rosenbaum, 2000). But the relationship between husband and wife still exists in the calculation of income tax payable. In its practice in Indonesia, there are quite a lot of couples who use separated scheme of TIN (NPWP) due to the number of married women who work, causing the wives prefers to be a career woman rather than a housewife.

Based on the results of a survey conducted by "accenture", a firm of management consultant, technology services and outsourcing present the survey results conducted to career women from 32 countries around the world, including Indonesia. The survey was conducted online to 4,100 career women from medium to large companies in 32 countries, each country contributing an average of 100 respondents. The results obtained from the survey, as many as $42 \%$ of women in Indonesia prefer to work than to stay at home, although they do not have financial problems. (Quoted from bisnis.liputan6.com).

State Personnel Agency (BKN) of 2015 also recorded that $29.50 \%$ of government structural officials are held by women. Even in the wider scope, as much as $46.03 \%$ professionals, managerial and technicians are women. In politics, female council members are around $17.32 \%$. While in the Micro and Small Industry (IMK), the role of women as business actors in the Indonesian economy is quite significant. Data result from the Micro and Small Industries (IMK) survey of 2015 by the Central Bureau of Statistics (BPS), show about $42 \%$ of IMK businesses are managed by women, while the remaining $58 \%$ are managed by men. In detail, female business actors in IMK are more visible in micro scale industry; industry that employs 1 to 4 people. In this category, as many as $44.12 \%$ of business actors are women. Meanwhile, in small scale industries that employ 5 to 19 people are only about $16.37 \%$ of female workers (Quoted from Thematic Gender Statistics: Gender Inequality in Economy, KPPPA-BPS, 2016). With this number, the potential role of women in development is very big and it can be a significant contributor in economic development.

Taxation laws in Indonesia also align gender equality between men and women, especially for married women. The main reason why the provision of taxation obligations for married women is the gender equality itself. In the case of the fulfillment of tax obligations, unmarried women who have their own income are required to register themselves to the Directorate General of Taxes office and for such registration will be granted TIN (NPWP) as a means of tax administration used as a self-identification or taxpayer identity to exercise tax rights and obligations as written in Article 2 of the Income Tax Law. Meanwhile, for women who have been bound by marriage, then they are given the freedom to determine whether to fulfill their own tax obligations or to follow the obligation of their husband taxation as written in Article 8 paragraph (2) letter c Income Tax Law i.e. husband and wife income are separately taxed if in the case of a wife choosing to exercise her own taxation rights and obligations. The separated fulfillment of the rights and obligations from the husband is not only in the circumstances of the wife chooses to be separated on her willingness but also in the case of husband and wife have separate lives based on the judge's decision as well as husband and wife entered into separation agreements of property and income, (Ruggie, 2014).

\begin{tabular}{lllll}
61,51 & 62,7 & 63,05 & 65,35 & 65,7 \\
38,49 & 37,3 & 36,95 & 34,67 & 34,3 \\
\hline 2011 & 2012 & 2013 & 2014 & 2015 \\
& & &
\end{tabular}

Figure 1 - The Percentage of Working Women with Marital Status Based on the Job Status, 2011-2015 
The development of the taxation provisions for married women, as regulated in Article 8 of Constitution No. 7 of 1983 on Income Tax has been amended several times, respectively by (i) Constitution No. 7 of 1991, (ii) Constitution No. 10 of 1994, (iii) Constitution No. 17 of 2000, and (iv) Constitution No. 36 of 2008. The separate taxation of husband and wife is regulated in Constitution No. 10 of 1994; only in case husband and wife have separated life and it is written by husband and wife based on separation agreement of property and income. In the case that the wife wishes to exercise her own taxation rights and obligations, it is regulated after the fourth amendment i.e. Constitution No. 36 of 2008. One of the reasons underlies the enactment of freedom for wives to choose to exercise their own taxation rights and obligations, is the increase of married women status that have jobs from year to year.

\section{THEORETICAL FRAMEWORK}

In Article 8 of Constitution No. 36 of 2008, concerning the Fourth Amendment to Constitution No. 7 of 1983 on Income Tax, it is stipulated provisions on the rules of income tax for married women, in terms of:

1. Husband Exercises the Tax Obligations as Head of Family (KK).

The definition of the head of family here is the head of the household who is responsible for decision making concerning the problems in the family both the problems that come from outside or from inside. Almost all women expressly state that men are the head of the family. The head of the family is carried by a father, a husband, or a brother. The exception that mentions the head of a family other than the man is the mother. The position of the mother as the head of the family occurs when the husband dies. In the taxation rules, the definition of the head of the family is more likely to be in a status within the family in which the rights and obligations of taxation of husband and wife are not separately sought. Implementation of taxation is enough to use the TIN (NPWP) of the husband. A wife can use husband's TIN (NPWP) as a means of tax administration without having to register herself to become a taxpayer to obtain TIN (NPWP) on her own name, which in other words the wife follows the husband's TIN (NPWP).

Basically, the tax system in Indonesia, according to the Income Tax Law, places the family as an economic entity, it means that the income or loss of all family members is combined as a taxable entity and the fulfillment of tax obligations is carried out by the head of the family. The husband as head of the family has the responsibility to report on their annual tax return (SPT) by incorporating all income received or accrued by his wife and other family members so that the wife has no the obligation to submit their annual tax return (SPT).

2. Husband and Wife have lived apart by Judge's decision (HB).

What is meant by husbands and wives to live apart according to the judge's decision is to divorce. Calculation of Taxable Income (PKP) and the tax imposition shall be made by each individual. The status of the taxation of the husband and wife shall be changed into the status of Unmarried (TK) including the calculation for the amount of non-taxable income (PTKP), only for themselves as a taxpayer and for family members who become dependents of each individual. If the wife previously has the same TIN (NPWP) with the husband's TIN (NPWP), whose tax code of administration is "001" or "999", it may be proposed for the elimination of TIN (NPWP) so that the wife can re-register to get a new TIN (NPWP) for herself. For dependence of the child, if the husband and wife have children, will be subjected to agreement whether the child is borne by husband or wife.

3. Husband and Wife Perform Written Agreement of Secession Separation (PH).

Marriage / prenuptial agreement (prenuptial agreement) is an agreement made before the marriage took place. The Marriage Law regulates the issue of marriage agreement in Article 29 of Constitution No. 1 of 1974. According to the Civil Code, with the existence of marriage, since then, the wealth of the previous property and the joint property with the husband and wife become one, unless there is a marriage agreement. The marriage agreement contains agreements on the separation of assets, income, and debt and as well as related to child custody. Separate treasury agreements result in husbands and wives 
becoming different individuals before the law. The same case happens with the tax law. If an unmarried husband and wife undertake a separation agreement of property and income in writing before marriage, then the wife should have her own TIN (NPWP) as mentioned in Article 2 paragraph (1) UU KUP and the calculation of tax payable is calculated based on the net income of husband and wife which is then calculated proportionally in accordance with the net income of each husband and wife. The wife who entered into the property separation agreement shall submit the Annual Income Tax Return (SPT) of the individual taxpayer in her own name separate from her husband's Annual Tax Return (SPT).

4. Wife Chooses to Exercise her Own Taxation Rights and Obligations (MT).

Provisions concerning the imposition of Income Tax for wives who choose to exercise their own taxation rights and obligations are regulated in Constitution No. 36 of 2008 concerning the Fourth Amendment to Constitution No. 7 of 1983 on Income Tax. Article 8 paragraph (3) stating that the net income of husband and wife as referred to in paragraph (2) points 2 and 3 shall be taxed on the basis of the merging of the husband and wife net income and the amount of tax to be paid by each husband and wife shall be calculated in accordance with the ratio of their net income. Circular Letter of General Tax Director Number: SE-29/PJ/2010 concerning Completion of Annual Income Tax Form of Individual Taxpayer for Married Women Conducting Separation Agreement of Property and Revenue, or Those who Choose to Exercise their Own Taxation Rights and Obligations, also describes rules and procedures for calculating income tax applicable to married women who choose to exercise their own taxation rights and obligations. The rules are as follows:

- It is compulsory to submit the Annual Income Tax Return of individual Taxpayer on her own name which is separate from the Annual Income Tax Return of her husband;

- The reported income is all income received or earned by a married woman within a taxable year, excluding the income of a minor child;

- The calculation of income tax payable in the Annual Income Tax Return of married women is based on the merging of the husband and wife's net income and the amount of income tax payable to the wife is calculated in accordance with the ratio of net income between husband and wife;

- The calculation of income tax payable for the above married woman also applies to married women as employees who have income solely received or obtained from an employer who has taxed by income tax of Article 21;

- The assets and liabilities/debts reported in the Annual Income Tax Return of the married woman are assets and liabilities owned/held at the end of the tax year;

- The procedure of filling the Annual Tax Return for married women is in accordance with the guidance of filling the Annual Tax Return of the Personal Taxpayer stipulated in Regulation of the Director General of Taxation No.34/PJ/2009 as lastly amended by Regulation of the Director General of Taxation No.36/PJ/2015.

\section{METHODS OF RESEARCH}

This study uses descriptive qualitative research method. The method used in this research is qualitative method with descriptive approach. Sugiyono (2016) argues that qualitative research method is a method used to examine the natural object condition, where the researcher is a key instrument, data collection technique is conducted in combination (triangulation), data analysis is inductive, and the result emphasis more on generalization. Firdaus (2017) argues that descriptive method is a method to examine the status of an object (can be human, event, etc.). Descriptive method learns about the issues of society as well as certain situations. This method is ex ost facto, it means that the data are collected after all the events have been completed/under way. Sugiyono (2016) argues that qualitative research is holistic (whole, integral) based on the overall social situation under study, include synergy aspects of the place, actors, and activity. According to $\mathrm{KBBI}$, analysis is an investigation of an event (composition, deeds, etc.) to find out the real situation (cause and effect, the core problem, and so on). 


\section{DISCUSSION OF RESULTS}

Income Tax Treatment of Married Woman Having an Income from one Employer. The application of tax laws for married women having an income from an employer follows the rules of Article 8 paragraph (1) of the Income Tax Law whose income is deemed final if it meets the requirements: (i) the income is received or obtained from one employer, (ii) has been taxed by income tax under Article 21 on Income Tax, (iii) has no relationship with the business or the free employment of the husband or other family members.

If the income received by a married woman does not meet the three conditions, then the income should not be considered final and should be backed by the husband's income. For example, a wife who works as a doctor in an X Hospital owned by her husband, then in the calculation of taxes, the net income of married women should be merged with the husband's net income.

Practically, there are two conditions for married women in the fulfillment of their taxation rights and obligation, (Meyer and Rosenbaum, 2001). The first condition, if the married woman chooses to exercise the taxation rights and obligations following the husband (spouse to husband). It means that the status of the tax obligation is borne to the Head of Family (KK); the husband as the head of the family is responsible for the tax obligations. In the ownership of TIN (NPWP), there is only one TIN (NPWP), it is husband's TIN (NPWP). Wife may use husband's TIN (NPWP) as a means of tax administration by affixing the code of branch "001" or "999" in the last three digits of the husband's TIN (NPWP), if it is necessary, the filling requirement in NPWP is at the company or institution where the married woman is working.

Therefore, the married women do not need to register themselves to get their own TIN (NPWP). Income that has been taxed by income tax under Article 21 are final. Thus, the net income received or earned by the wife is not combined with the husband's net income, in the case of the calculation of the income tax payable. For example, an employee of Bank Mandiri who works as a teller and has been taxed by Article 21 on Income Tax for the income she receives. If she follows her husband, she does not need to submit the Annual Tax Return; it is only tax obligation which is made by the husband. While the tax that is already taxed by the company is considered as final and is reported in the annual tax return for private person of husband in Appendix III Part A numeral of 15 SPT 1770 or Appendix II Part A numeral of 13 SPT 1770 S.

The second condition if the married woman chooses to exercise the taxation rights and obligations separately from her husband. Taxation regulation of this married woman refers to Article 8 paragraph (2) letter c of the Income Tax Law; if the wife is willing to choose to exercise her own taxation rights and obligations; where the husband and wife income are taxed separately. The relationship of husband and wife is still visible in the calculation of the tax payable.

Article 8 Paragraph (3) of the Income Tax Law explains how the tax calculation between husband and wife who choose to exercise the taxation rights and obligations separately; the net income of the husband and wife is taxed on the basis of the merged net income of husband and wife, and the amount of tax which must paid by each husband and wife is calculated in accordance with their net income ratio. In addition, in the Income Tax Act, the taxation laws of married women who choose to exercise the rights and obligations separately from their husbands are also regulated in SE-29/PJ/2010 concerning the Inclusion of Income Tax Statement of Individual Taxpayers for Married Women Conducting the Agreement Separation of Property and Income or Who Choose to Exercise Their Own Taxation Rights and Obligations. The obligation to report annual tax return is not only done by husband but also wife. Each of them conveys the amount of income received or earned in a tax year.

If we carefully observe it, married women who work as an employee in a company, institution or agency with the good intention of registering for a TIN (NPWP) on its own behalf, will feel aggrieved because it is likely to pay a tax shortfall compared to an employee whose TIN (NPWP) is inducted into husband. Most of women who have a job before 
marriage, they have already had TIN (NPWP) of their own due to the requirements submitted by the company where they worked. The reason is not to be subjected to Article 21 with a higher rate of $20 \%$ than the rate applied to ordinary taxpayers who have NPWP. The rule refers to Article 21 of the Income Tax Law No. 38 of 2008 and Regulation of the Minister of Finance No. 252/KMK.03/2008 Article 20 paragraph (1) stating that the recipients of income, who are taxed by Article 21 Income Tax, who do not have TIN (NPWP) shall be subject to withholding of Article 21 Income Tax at a rate higher $20 \%$ compared to which is applied to ordinary taxpayers who have NPWP. Paragraph (2) states that the amount of Income tax of Article 21 that must be taxed against employees who have TIN (NPWP) is $120 \%$ of the total of income tax; in which it should be taxed due to Article 21 where the taxpayers have TIN (NPWP). On that basis, employers of a company, institution, or agency prefer to register themselves in order to get TIN (NPWP) rather than having to bear higher taxes than those who already have NPWP.

Calculation of Income Tax Payable. The calculation of income tax payable, for married women having an income from one employer here, is based on two conditions which been described previously. The legal basis underlies the calculation of income tax for wives who choose not to be separated is in Article 8 paragraph (1) of the Income Tax Law where the tax of the wife's income is final, while the wife who chooses to exercise her taxation rights and obligations is in Article 8 paragraph (3) of the Income Tax Law and its explanation and SE29/PJ/2010. The following is the presentation of the examples of tax calculations payable for each of the conditions of married women who have an income from one employer but have different way in fulfillment of taxation rights and obligations.

Condition I (The wife does not exercise her own taxation rights and obligations). Mr. Surnama and Mrs. Surila is a married couple who each works as a civil servant (PNS) in one of the government agencies in the city of Surabaya. Both of them have dependents of three children who are still going through education. Mr. Surnama's net income during the year is amounted to IDR 357.175.416 and Mrs. Surila net income is amounted to IDR 241.836.144. Mr. Surnama's TIN (NPWP) is 06.677.878.3-589.000 and Mrs. Surila's TIN (NPWP) is 06.677.878.3-589.001. Mrs. Surila is willing to have the fulfillment of taxation rights and obligations separately from Mr. Surnama. Here is the calculation of income tax 21 if the wife does not exercise her own taxation rights and obligations:

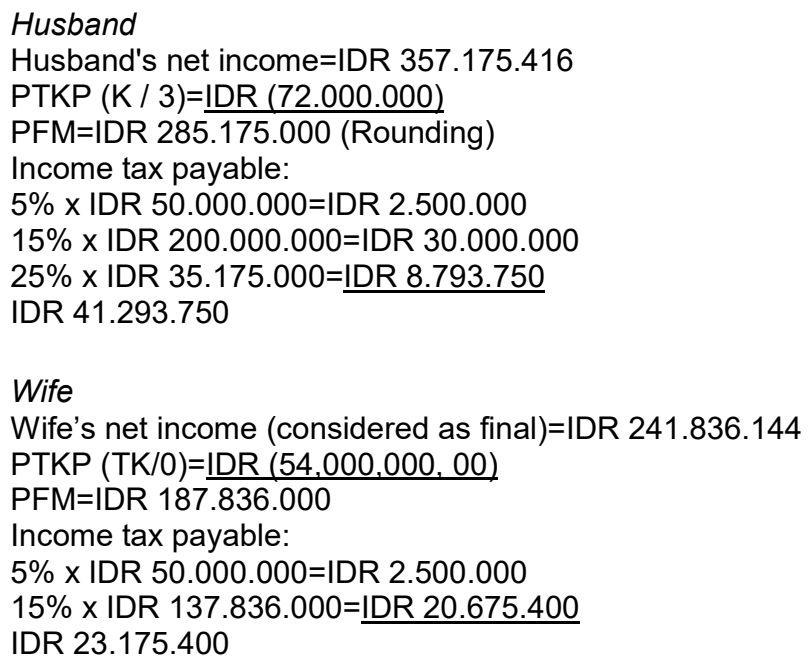

In this condition, the net income received or obtained by the wife is not merged with the husband's net income because it is considered as final, because it comes from one employer, namely the government agency of Surabaya City. So that in the calculation of tax payable, there is no relationship with each other (final). Tax of income tax 21 by the Surabaya government agency, will be presented to the wife as proof of tax deduction in a piece of evidence. At the end of the year, in the time of the Annual Income Tax Return report, 
the piece of evidence that has been submitted to the wife will be used as a tax credit for Income Tax 21 so that the amount to be paid is nil.

Condition II (The wife exercises her own taxation rights and obligations). Condition II uses the same illustration with the condition I. However, TIN (NPWP) of each couple is different because the wife chooses to exercise taxation rights and obligations separately from her husband. Mr. Surnama's TIN (NPWP) is 12.345.678.9-678.000 and Mrs. Surila's TIN (NPWP) is 88.999.000.2-675.000. By using the same illustration with condition $I$, the calculation of income tax 21 is when the wife chooses to exercise her own taxation rights and obligations; it is presented in the following description:

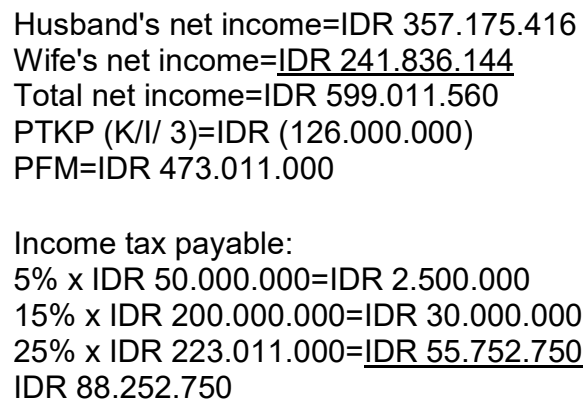

Income tax payable borne by husband: IDR 357.175.416 x IDR 88.252.750=IDR 52.622.878 IDR 599.011 .560

Income tax payable borne by wife:

IDR 241.836.144 x Rp88.252.750=IDR 35.629.871 IDR 599.011.560

Table 1 - Comparison of Income Tax Payable of 21 between Condition I and Condition II (In units of Rupiah)

\begin{tabular}{|c|c|c|c|c|c|}
\hline \multirow{2}{*}{ ITP 21 } & \multicolumn{2}{|c|}{ Condition I } & \multicolumn{3}{c|}{ Condition II } \\
\cline { 2 - 6 } & $\begin{array}{c}\text { Income tax } \\
\text { Payable }\end{array}$ & Lack of Payment & $\begin{array}{c}\text { Income tax } \\
\text { Payable }\end{array}$ & $\begin{array}{c}\text { Credit } \\
\text { Tax }\end{array}$ & Lack of Payment \\
\hline Husband & 41.293 .750 & Nil & 52.622 .878 & 41.293 .750 & 11.329 .128 \\
\hline Wife & 23.175 .400 & Nil & 35.629 .871 & 23.173 .400 & 12.454 .471 \\
\hline
\end{tabular}

From case illustration of condition I and condition II which have been presented above, we can know that income tax payable of Article 21 by husband and wife in each different condition. Condition I is if the wife does not choose to exercise taxation rights and obligations separately from husbands, it states that income tax should paid by the husband is IDR 41.293.750 and the income tax should be paid by the wife is for IDR 23.175.400. There is no income tax that is underpaid by them so it is stated that lack of payment is nil. This is because no more payments after the end of the year, so that the Annual Income Tax Return of the husband is nil. Therefore, there is no Income Tax of Article 29 should be paid by the husband.

While in the second condition when the wife chooses to exercise taxation rights and obligations separately from her husbands, income tax payable by a husband is IDR 52.622.878 and wife is IDR 35.629.871. Mrs. Surila's income tax of Article 21 which has been taxed by the employer is IDR 23.175.400. But Mrs. Surila's chooses to exercise taxation right and obligation by herself, and then her income tax is IDR 35.629.871. Income tax that has been taxed by the employer can be used as a tax credit by Mrs. Surila. Capital tax obligations Surila are as follows. 
Due to the lack of payment to the income tax, then Mrs. Surila shall pay to the state treasury with due date of March 30 in the next tax year. In the table above, it can be concluded that there is a significant underpayment of income tax between them. Condition I mentions that the lack of payment is nil. While the condition II shortly mentions the lack of payment is IDR 11.329.128 to Mr. Surnama and IDR 12.454.471 for Mrs. Surila.

Why the difference between income tax payable condition I and condition II can actually happen? If elaborated mathematically, the most influencing factor is the calculation of PKP and income tax rate layers. In condition II, the calculation of income tax payable for husband and wife who exercise taxation rights and obligations separately is by combining the husband and wife net income and then reduced by PTKP. This causes the number of married couple combined income taxable, after deducting with PTKP, the amount is IDR 50.000 .000 will be charged the lower rate $(5 \%)$ only once. The rest will be subject to the rate of $15 \%$. However, on the condition I, PKP is up to IDR 50.000.000; it will be charged the lower rate twice, in the time of calculation of income tax payable of the husband and income tax payable of the wife. So, the part of PKP that should have taxed $15 \%$ rate is subjected to a low rate of $5 \%$.

\section{CONCLUSION AND SUGGESTIONS}

Based on the discussion, it can be concluded that the provision of taxation for married women having an income from one employer in which it has been deducted by Article 21 on Income Tax under Article 8 paragraph (1) of the Income Tax Law is considered as final if the income of the wife is received or obtained solely from one employer and have no relationship to the husband's free business or work. Report of Annual Income Tax Return (SPT) for married women having an income from one employer is still exercised by her husband as long as the wife does not choose to exercise the taxation rights and obligations separately.

If the wife chooses to exercise the tax separately from her husband, the wife must perform self-assessment to calculate her self-payable tax and must submit the Annual Income Tax Return (SPT) regardless of the obligation of the husband to submit the Annual Income Tax Return (SPT). The net income for married couples who exercise separate taxation rights and obligations is done by combining the net income of each husband and wife and the amount of tax payable; it is calculated in accordance with their net income ratio. Laws regulating married women who wish to exercise their taxation rights and obligations separately from their husbands are provided in Article 8 paragraph (2) letter $c$ and paragraph (3) of the Income Tax Law and SE-29/PJ/2010.

The consequence of applying different taxation rules of the two conditions of the married woman is that if the married woman who works from one employer then chooses to exercise her taxation rights and obligations separately from her husband, it will have an impact on the amount of tax greater than the married woman who choose to exercise the taxation rights and obligations jointly with the husband. Therefore it causes a gap in terms of taxation rules. Because, the existing taxation rules of Indonesia put the family as an economic unity.

The implementation of regulation concerning tax obligations for married woman having an income from one employer, have not yet met the point of justice. Taxation rules in Indonesia still use the family as an economic unity that can be taxed even though the wife wants to choose to exercise taxation rights and obligations separately from her husband and have her own TIN (NPWP). Whereas, before the tax law, they are independent taxpayers so that both are obliged to submit their Annual Income Tax Return (SPT).

It is suggested to hold counseling and dissemination through print and online media such as advertisements on media or being on-air on radio and television delivered by tax officials as an extension of the government's hand on the consequences of tax rules for married women who choose to exercise taxation rights and obligations separately from her husband. In addition, the Tax Office should actively provide understanding for taxpayers especially for married women who wish to register themselves to get TIN (NPWP) on their behalf and invite Human Resources Development (HRD) from companies and treasurer of 
salary from central or local government work unit, which is located in its working area to give more deeply counseling and dissemination about the provisions of taxation related to married women, so that the information provided can be disseminated.

\section{REFERENCES}

1. Sugiyono, 2016. Metode Penelitian Kuantitatif, Kualitatif, dan R\&D. Bandung : Alfabeta Bandung

2. Blundell, R., Duncan, A., McCrae, J., \& Meghir, C. (2000). The labour market impact of the working families' tax credit. Fiscal Studies, 21(1), 75-104.

3. Eissa, N., \& Hoynes, H. W. (2004). Taxes and the labor market participation of married couples: the earned income tax credit. Journal of public Economics, 88(9), 1931-1958.

4. Ruggie, M. (2014). The state and working women: A comparative study of Britain and Sweden. Princeton University Press.

5. Meyer, B. D., \& Rosenbaum, D. T. (2001). Welfare, the earned income tax credit, and the labor supply of single mothers. The quarterly journal of economics, 116(3), 1063-1114.

6. Eissa, N., \& Hoynes, H. W. (2006). Behavioral responses to taxes: Lessons from the EITC and labor supply. Tax policy and the economy, 20, 73-110.

7. Meyer, B. D., \& Rosenbaum, D. T. (2000). Making single mothers work: Recent tax and welfare policy and its effects (No. w7491). National bureau of economic research.

8. Firdaus, 2017. Dasar-Dasar Penelitian. Jakarta : BPPK

9. Dokumen Publik atau Peraturan Perundang-Undangan

10. Undang-Undang Nomor 36 Tahun 2008 tentang Perubahan Keempat atas UndangUndang Nomor 7 Tahun 1983 tentang Pajak Penghasilan.

11. Undang-Undang Nomor 16 Tahun 2009 tentang Perubahan Keempat atas UndangUndang Nomor 6 Tahun 1983 tentang Ketentuan Umum dan Tata Cara Perpajakan.

12. Peraturan Pemerintah Nomor 74 Tahun 2011 tentang Tata Cara Pelaksanaan Hak dan Pemenuhan Kewajiban Perpajakan.

13. Peraturan Menteri Keuangan Nomor 243/PMK.03/2014 tentang Surat Pemberitahuan.

14. Direktorat Jenderal Pajak. Peraturan Direktur Jenderal Pajak Nomor PER-51/PJ./2008 tentang Tata Cara Pendaftaran Nomor Pokok Wajib Pajak bagi Anggota Keluarga.

15. Peraturan Direktur Jenderal Pajak Nomor: Per-36/Pj/2015 tentang Perubahan Ketiga atas Peraturan Direktur Jenderal Pajak Nomor

16. Per-34/Pj/20130 tentang Bentuk Formulir Surat Pemberitahuan Tahunan Pajak Penghasilan Wajib Pajak Orang Pribadi dan Wajib Pajak Badan Beserta Petunjuk Pengisiannya.

17. Peraturan Direktur Jenderal Pajak Nomor: Per-38/Pj/2013 tentang Perubahan Atas Peraturan Direktur Jenderal Pajak Nomor

18. Per-20/Pj/2013 tentang Tata Cara Pendaftaran dan Pemberian Nomor Pokok Wajib Pajak, Pelaporan Usaha dan Pengukuhan Pengusaha Kena Pajak, Penghapusan Nomor Pokok Wajib Pajak dan Pencabutan

19. Pengukuhan Pengusaha Kena Pajak, serta Perubahan Data dan Pemindahan Wajib Pajak.

20. SE-29/PJ/2010 Tentang Pengisian Surat Pemberitahuan Tahunan Pajak Penghasilan Wajib Pajak Orang Pribadi bagi Wanita Kawin yang Melakukan Perjanjian Pemisahan Harta dan Penghasilan atau yang Memilih untuk Menjalankan Hak dan Kewajiban Perpajakannya Sendiri.

21. Putusan Mahkamah Konstitusi Nomor : 69/PUU-XIII/2015 Tahun 2015 tentang Pengujian Undang-Undang Nomor 5 Tahun 1960 tentang Peraturan Dasar Pokok-Pokok Agraria dan Undang-Undang Nomor 1 Tahun 1974 tentang Perkawinan. 